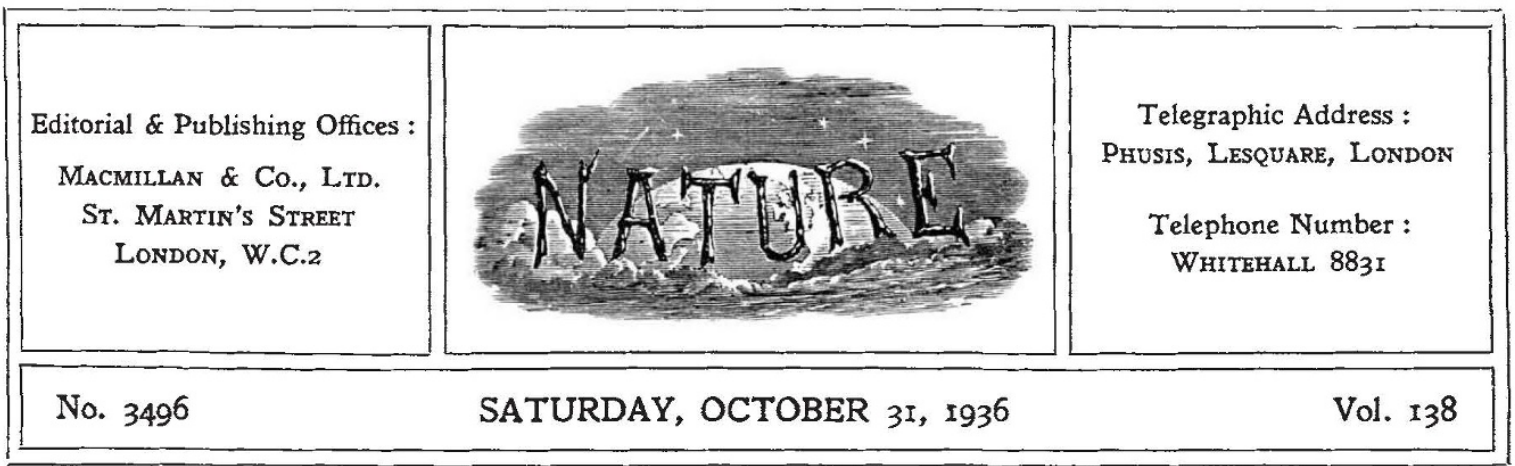

\title{
Taxation, Administration and Research in East Africa
}

T has sometimes been questioned by purists in British constitutional practice whether it is advisable that the ministers of His Majesty's Government in charge of Departments of State should have personal experience of conditions in the affairs they are called upon to administer. Whichever way opinion may incline, it is patent that Mr. Ormsby-Gore's tenure of office will afford concrete material for judgment. His knowledge of conditions in the British dependencies is greater than that of any previous holder of the office of Colonial Secretary, and has been approached by none since the days of Joseph Chamberlain. Mr. Ormsby-Gore does not propose to allow his knowledge to lie fallow; and already both in matters which have arisen under his jurisdiction and in those which he has inherited from his predecessor in office, it has enabled him to show a ready appreciation of the necessity for prompt action and a strong forward policy in native affairs in Africa to remedy or to forestall the dangers, to which he is fully alive, arising out of the dislocation threatening the welfare of African peoples in the present rapid development of economic and social circumstances.

Mr. Ormsby-Gore's dispatch to the Governor of Nyasaland dealing with the report of the Committee on emigrant labour from the Protectorate (see NatuRE, 137, 921) is remarkable alike for its independence of judgment and its well-balanced assessment of the conflicting forces, which have to be taken into account in devising measures to meet the trend of circumstances threatening the future stability of the country and its peoples. He intimates that he shares to the full the anxiety of the members of the Committee, and that he agrees to the necessity for immediate steps to remedy a state of affairs, which seems to be bringing hardship and misery to many members of the native community. When he suggests, however, that less spectacular measures may serve the purpose of such of the remedial proposals of the Committee as he has been unable to accept in full, his reasons are in plain view. He goes on to point out that expenditure on a scale, which since 1930 has allocated more than $£ 4,200,000$ to the development of the Protectorate and to raising the standard of living of the native inhabitants, cannot continue.

The crux of the native situation in Nyasaland is undoubtedly the hut and poll tax. The Governor of the Protectorate, it is true, and as it appears from the dispatch of the Colonial Secretary, does not admit the contention of the Committee that taxation is the primary cause of the excessive emigration; but Mr. Ormsby-Gore, while recog nizing the influence of a higher standard of living, of the spirit of adventure and of the attraction of conditions of employment in neighbouring territories, holds that the hut and poll tax must be regarded as a most important factor in the present situation. It bears heavily, he maintains, on natives in those areas in which the opportunities of obtaining employment or of selling crops for export are scarce. In this more limited sense, there cannot be two opinions but that he is correct. He suggests, therefore, that taxation in such areas should be reduced immediately. At the same time, he expresses himself as not in favour of the drastic methods of control and restriction of movement advocated in the report of the Committee. To some, Mr. Ormsby-Gore may appear to have been over-cautious; but in initiating changes among African peoples a certain restraint is no unwise policy. 
It is interesting to note how closely in principle the suggestions of the Colonial Secretary addressed to the Governor of Nyasaland are in accord with the attitude of Sir Alan Pim when he touches upon native problems in his recent report on the financial position in Kenya*. Sir Alan Pim's previous experience of adverse conditions among the peoples of the Protectorates of South Africa affords assurance that his diagnosis of factors detrimental to the native population of Kenya may be accepted as well grounded. That this, at any rate, is the conclusion at which Mr. OrmsbyGore has arrived is indicated by the fact that he has intimated to the Governor, Sir Joseph Byrne, that the recommendations of the report are generally acceptable and should be adopted as a whole.

Not only does Sir Alan Pim regard the system of registration and labour control with little favour, but he also holds taxation of the native, as at present constituted, to be one of the principal factors operating to the detriment of social and economic conditions among them. The case for and against the hut and poll tax, which is estimated to produce the sum of $£ 540,000$ in the current year, is stated in detail in this report. No more need be said here than that broadly the conclusion is that this form of taxation is a cause of poverty, is difficult to assess, difficult to collect, and a source of injustice.

Hut and poll taxes were imposed originally on the natives of Africa, as is well known and as has been recalled frequently in recent discussion, in great measure to spur the native to greater activity as a producer and to stimulate and ensure a larger and more steady flow of labour into European employment. This object has been attained at a cost of no little disintegration in native social and economic institutions. In accordance with the recommendations of this report, revision in Kenya is now under consideration.

Sir Alan Pim's recommendations for retrenchment in the finances of Kenya, while sufficiently drastic, though in the opinion of some disappointing in result, are sympathetic towards native claims for consideration. In regard to the medical service, for example, to which the native looks in an increasing degree, he points out that since the Great War a complete change in outlook has taken place, and enlargement rather than retrenchment must be anticipated, although he indicates

* Report of the Commission appointed to enquire into and report on the Financial Position and System of Taxation of Kenya. (Colonial No. 116.) Pp. vii +282. (London: H.M. Stationery Offle, 1936.) 98. the road to one possible economy in the development of the non-European sub-medical staff. At the same time, in the matter of scientific research he is by no means over-generous; and although he notes with some approval the desire of the Director of Medical Services to form an Institute of Medical Research for East Africa in Kenya, his general position is that what may be regarded as 'long-term' research must be met from outside sources. This will come as something of a setback to those who appreciate the urgency of inquiry on a much greater scale than as yet has seemed possible without official support on such matters as the nutrition, physical development and the mental capacities of the natives of East Africa, to mention one group only of questions needing investigation.

That there is a wide field for scientific research in matters directly affecting the life of both white settlers and natives in Kenya, and that it is largely untouched, has been deplored on many occasions. It is possible that the solution of the difficulties, financial and other, may lie along lines suggested in the report of this Commission. It is there pointed out that local research in agriculture, for example, might be associated with more advanced study in a centre at either the research institute at Amani in Tanganyika or at the centre for higher education at Makerere in Uganda. Such a solution would facilitate a scheme of co-operation as between the several Territories in East Africa, which might be made sufficiently wide to cover the whole field of appropriate research.

The possibilities of a scheme of co-ordinated and co-operative research in East Africa, in which responsibility for the various branches of inquiry would be distributed among the local governments, deserve to be explored further. Such a question may scarcely be considered to fall within the terms of reference of the newly appointed Commission, which is to proceed under the chairmanship of Lord De La Warr to Uganda early next year, for the purpose of inquiring into the constitution and working of the centre for higher education at Makerere and affiliated institutions, as well as to examine and report on their effect on the educational institutions and systems of the Territories affected (The Times, Oct. 20). At the same time, it is a matter upon which even a passing expression of opinion from the Commission, or better a suggestion as to a line of inquiry, would be of inestimable value as a stage towards specific action. 